\section{Effect of an Enzymatic Blend and Yeast on the Performance, Carcass Yield and Histomorphometry of the Small Intestine in Broilers from 21 to 42 Days of Age}

\section{-Author(s)}

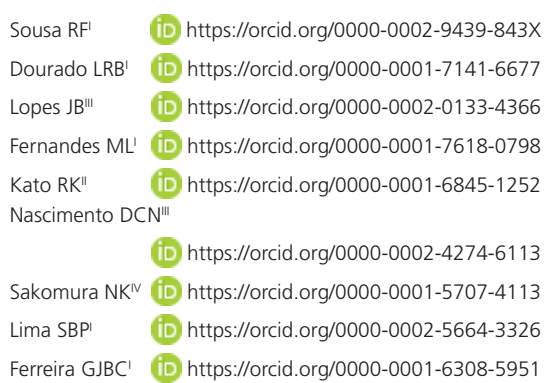

Universidade Federal do Piauí, Campus Profa Cinobelina Elvas - Departamento de Zootecnia Bom Jesus, PI, Brasil.

Biogenic Group-nutrição e saúde animal - Taboão da Serra, SP, Brasil.

III Universidade Federal do Piauí - Campus Universitário Ministro Petrônio Portella - Departamento de Ciência animal - Teresina, PI, Brasil.

v Universidade Estadual Paulista, Faculdade de Ciências Agrárias e Veterinárias - Departamento de Zootecnia - Jaboticabal, SP, Brasil.

\section{Mail Address}

Corresponding author e-mail address Regina Fialho de Sousa

Rua Pedro Paulo de Souza, Goiânia, GO, 74663-520, Brasil.

Phone: +62 98106-9081

Email: regina-so-fia@hotmail.com

\section{-Keywords}

Cane sugar, Microscopy, metabolism, Saccharomyces cerevisiae, Xylanase.

\section{ABSTRACT}

The present study was conducted to evaluate the performance, carcass yield, and histomorphometry of the small intestine of broilers fed yeast sugarcane supplemented with enzymatic blend from 22 to 42 days of age. Seven hundred broiler chicks were distributed in a completely randomized design in a factorial design $(2 \times 3+1)$, two levels of the enzyme blend ( 0 and $200 \mathrm{~g} /$ ton), three protein levels $(0 \%, 6 \%$ and $12 \%$ ) and a control diet. The level of $6 \%$ yeast showed higher feed intake and weight gain after 33 days. From 22 to 42 days there was no significant effect $(p<0.05)$ to the use of yeast in animal performance, carcass yield and cuts. At 42 days an interaction between the factors for width and crypt depth in the duodenum and jejunum, respectively, was observed. The inclusion of yeast in the diets for broilers from 22 to 42 days did not affect the performance and yield of the carcass. Yeast increased the muscle wall of the jejunum. The use of the enzymatic blend did not influence performance but affected the integrity of the intestinal mucosa.

\section{INTRODUCTION}

Sugarcane yeast (Saccharomyces cerevisiae) is a microorganism derived from alcoholic fermentation in the sugar cane industry for the production of to produce alcohol (Franco \& Langdraf, 2008), with great potential to be used in animal nutrition in substitution of soybean meal, since it is a highly proteic food. According to Rostagno et al. (2011) sugarcane yeast has $37.20 \%$ of protein, besides considerable amounts of minerals and lipids. Despite the high nutritional value, this food has a blend cell wall composed of non-starch polysaccharides (NSPs) such as mannans, glucans, xylans and chitin, which surround the nutrients, making them unavailable to animals (Fleuri \& Sato, 2007).

The main consequence attributed to foods rich in PNAs is loss of zootechnical performance (Mourão \& Pinheiro, 2009), linked to the increase in the viscosity of the food bolus and, therefore, to avoid the access of the digestive enzymes to the substrate (Knudsen, 2014) and reduction at the height of intestinal villi (Sadeghi et al., 2015).

These effects can be attenuated with the use of exogenous enzymes such as xylanases, glucanases, mannanases, among others. These enzymes that act on ingredients with high levels of NSPs, hydrolyzing the chemical bonds of these polysaccharides, increasing the digestibility, reducing the viscosity of the digest and improving the availability of all the nutritional components of the food (Ribeiro et al.2011)

Enzymes exogenous are widely exploited in foods of plant origin, with wheat, rye and barley, however, little information is available regarding the use of this technological advent to aid in the digestibility 
Sousa RF, Dourado LRB, Lopes JB,

Fernandes ML, Kato RK,

Nascimento DCN, Sakomura NK,

Lima SBP, Ferreira GJBC

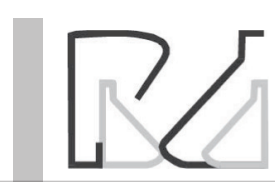

Effect of an Enzymatic Blend and Yeast on the Performance, Carcass Yield and Histomorphometry of the Small Intestine in Broilers from 21 to 42 Days of Age

geographical coordinates: Latitude - 09 $04^{\prime} 28^{\prime \prime} \mathrm{S}$, Longitude - 44 21'31' W

\section{Animals and Treatments}

A completely randomized design was used in a $2 \times 3$ +1 factorial scheme, with two levels of enzyme blend ( 0 and $200 \mathrm{~g} /$ ton), three levels of yeast inclusion $(0,6$ and $12 \%$ ) and a control diet, making seven treatments with five replicates and 20 chicks per experimental unit.

The treatments used were: T1-reference diet with corn and soybean (PC); T2-reference diet with corn and soybean base with reduction of $70 \mathrm{kcal}$ of metabolizable energy of the diet (NC) with $0 \%$ of yeast without enzymatic blend; T3- NC+ $6 \%$ yeast without enzymatic blend ; T4-NC+ $12 \%$ yeast without enzyme on animal experimentation - CEEA/UFPI with opinion number $087 / 2012$. The city is located under

The project was approved by the ethics committee Table 1 - Composition of the experimental diets for broilers between 22 to 42 days of age phase

\begin{tabular}{|c|c|c|c|c|c|c|c|}
\hline \multirow[t]{2}{*}{ Ingredient(kg) } & \multirow{2}{*}{ PC } & \multirow{2}{*}{ NC } & \multicolumn{5}{|c|}{ EB+ Yeast } \\
\hline & & & $6 \%$ & $12 \%$ & $0 \%+E B$ & $6 \%+\mathrm{EB}$ & $12 \%+\mathrm{EB}$ \\
\hline Corn & 67.156 & 68.653 & 67.428 & 66.047 & 68.653 & 67.428 & 66.047 \\
\hline Soybean meal & 25.274 & 25.110 & 20.151 & 15.339 & 25.110 & 20.151 & 15.339 \\
\hline Soy oil & 2.329 & 1.002 & 1.023 & 1.071 & 1.002 & 1.023 & 1.071 \\
\hline Phosphatebic. & 1.662 & 1.659 & 1.636 & 1.611 & 1.659 & 1.636 & 1.611 \\
\hline Limestone & 0.921 & 0.923 & 0.925 & 0.926 & 0.923 & 0.925 & 0.926 \\
\hline $\mathrm{NaCl}$ & 0.457 & 0.457 & 0.429 & 0.402 & 0.457 & 0.429 & 0.402 \\
\hline L - lysine & 0.331 & 0.333 & 0.339 & 0.341 & 0.333 & 0.339 & 0.341 \\
\hline DL- methionine & 0.277 & 0.274 & 0.309 & 0.343 & 0.274 & 0.309 & 0.343 \\
\hline $\mathrm{L}$ - threonine & 0.099 & 0.097 & 0.117 & 0.135 & 0.097 & 0.117 & 0.135 \\
\hline L- valine & 0.086 & 0.084 & 0.112 & 0.138 & 0.084 & 0.112 & 0.138 \\
\hline L- arginine & 0.000 & 0.000 & 0.108 & 0.211 & 0.000 & 0.108 & 0.211 \\
\hline L- tryptophan & 0.008 & 0.008 & 0.023 & 0.037 & 0.008 & 0.023 & 0.037 \\
\hline Min. Vitamin Supplement1 & 0.400 & 0.400 & 0.400 & 0.400 & 0.400 & 0.400 & 0.400 \\
\hline Inert2 & 1.000 & 1.000 & 1.000 & 1.000 & 0.980 & 0.980 & 0.980 \\
\hline Yeast & 0.000 & 0.000 & 6.000 & 12.000 & 0.000 & 6.000 & 12.000 \\
\hline EB3 & 0.000 & 0.000 & 0.000 & 0.000 & 0.020 & 0.020 & 0.020 \\
\hline TOTAL & 100.00 & 100.00 & 100.00 & 100.00 & 100.00 & 100.00 & 100.00 \\
\hline \multicolumn{8}{|l|}{ Calculated Composition } \\
\hline $\mathrm{PB}(\%)$ & 17.690 & 17.736 & 17.700 & 17.700 & 17.736 & 17.700 & 17.700 \\
\hline EM (kcal/kg) & 3100 & 3030 & 3030 & 3030 & 3030 & 3030 & 3030 \\
\hline $\mathrm{Ca}(\%)$ & 0.850 & 0.850 & 0.850 & 0.085 & 0.850 & 0.850 & 0.085 \\
\hline P disp. (\%) & 0.420 & 0.420 & 0.420 & 0.420 & 0.420 & 0.420 & 0.420 \\
\hline Lysine dig. (\%) & 1.045 & 1.045 & 1.045 & 1.045 & 1.045 & 1.045 & 1.045 \\
\hline Methionine dig. (\%) & 0.514 & 0.513 & 0.539 & 0.565 & 0.513 & 0.539 & 0.565 \\
\hline Met + cist dig. (\%) & 0.760 & 0.760 & 0.760 & 0.760 & 0.760 & 0.760 & 0.760 \\
\hline Threonine dig. (\%) & 0.679 & 0.679 & 0.679 & 0.679 & 0.679 & 0.679 & 0.679 \\
\hline Trypt. disp. (\%) & 0.188 & 0.188 & 0.188 & 0.188 & 0.188 & 0.188 & 0.188 \\
\hline Arginine dig. (\%) & 1.047 & 1.047 & 1.047 & 1.047 & 1.047 & 1.047 & 1.047 \\
\hline Valine disp. (\%) & 0.815 & 0.815 & 0.815 & 0.815 & 0.815 & 0.815 & 0.815 \\
\hline Fenil. dig. (\%) & 0.794 & 0.796 & 0.732 & 0.672 & 0.796 & 0.732 & 0.672 \\
\hline Isoleucine dig. (\%) & 0.657 & 0.657 & 0.631 & 0.586 & 0.657 & 0.631 & 0.586 \\
\hline Sodium & 0.200 & 0.200 & 0.200 & 0.200 & 0.200 & 0.200 & 0.200 \\
\hline
\end{tabular}

'Guarantee levels per kg of product: folic acid - 162.50mg; chlorohydroxyquinoline - 7500.00 mg; vitamin A - 1400062.50 Ul; vitamin B1 - 388.00 mg; vitamin B12 - 2000.00 mcg; vitamin B2 - 1000.00 mg; vitamin B6 - 520.00 mg; vitamin D3 - 360012.00 Ul; vitamin E - 2500.00 mg ; vitamin K 3 - 300.00 mg; niacin - 7000.00 mg; salinomycin - 16.500 mg; pantothenic acid - $2600.00 \mathrm{mg}$; choline chloride - $71.590 \mathrm{mg}$; selenium $-75.00 \mathrm{mg}$; iron sulphate 11.250 mg; manganese monoxide - 18740.00 mg; copper sulphate - 1996.00 mg; iodine - $187.47 \mathrm{mg}$; zinc - $17500.00 \mathrm{mg}$; 2inert- washed sand; 3EB- enzymatic blend ( $\alpha$-galactosidase. galactomannanase. xlanase e $\beta$-glucanase). 
Sousa RF, Dourado LRB, Lopes JB, Fernandes ML, Kato RK, Nascimento DCN, Sakomura NK, Lima SBP, Ferreira GJBC
Effect of an Enzymatic Blend and Yeast on the Performance, Carcass Yield and Histomorphometry of the Small Intestine in Broilers from 21 to 42 Days of Age blend ; T5- NC + $0 \%$ yeast with enzyme blend ; T6-NC $+6 \%$ yeast with enzyme blend ; T7-NC $+12 \%$ yeast with enzyme blend .

The diets (Table 1) wereformulated by means of adaptations between $\operatorname{Ross}^{\circledR}$ recommendations and Rostagno et al. (2011).

The enzymatic blend had the enzymes $\alpha$-galactosidase, galactomannanase, xilanase e $\beta$-glucanase, and was added to the diet in the amount of $200 \mathrm{~g} / \mathrm{ton}$.

On the 22nd day, the broilers (700 males of the Ross lineage) were weighed and evenly distributed in the pens, with a floor covered with rice hulls. Each experimental unit had a pendular drinking fountain and a tubular feeder for supplying water and feed. A 24-hour light regime (natural + artificial) was used.

\section{Performance}

At 33 and 42 days, the performance variables of the animals (feed intake, weight gain and feed to gain ratio) were evaluated.

\section{Histomorphometry of the small intestine}

At 42 days of age, one animal from each plot was euthanized. Then, a fragment $(2.0 \mathrm{~cm})$ of each portion of the small intestine (duodenum, jejunum and ileum: from the Meckel's diverticulum) was collected for the morphometric study.

The fragments were opened longitudinally, washed in distilled water, extended by the serous tunic and fixed in Bouin's solution for 24 hours, followed by washing in running water for 12 hours and maintaining it in alcohol $50^{\circ} \mathrm{Gl}$ (Behmer, 2003). Subsequently, the samples were submitted to standard histological processing, were included in Histopar ${ }^{\circledR}$ paraffin (Easypath - Erviegas Ltda.) and sectioned in the thickness of $4 \mu \mathrm{m}$, using semiautomatic rotating microtome (Leica ${ }^{\circledR}-\mathrm{RM} 2245$ ). The sections were stained with hematoxylin and eosin (Hu et al. 2012, Sousa et al., 2015). Colorless stained glass 500 was used (Acrilex ${ }^{\circledR}$ ) to assemble the laminae (Paiva et al.2006).

Trinocular optical microscope (Nova Optical Systems) was used with a TOUPCAM TM digital camera (5 Megapixels) coupled and the software TopView ${ }^{\circledR}$ 3.7 for the reading of histological laminae. In each slide 10 villi, 10 crypts and 10 walls were identified, in which the following variables were measured: perimeter, height and width of villi, depth and crypt width and thickness of the muscular layer of the intestinal wall.

Measurements of villi $(V)$ were performed from the base to its apex; The crypts (C), was considered the closest to the measured vili; Thickness of the intestinal wall musculature (PM), was from lamina appropriate to serosa (Figure 1).

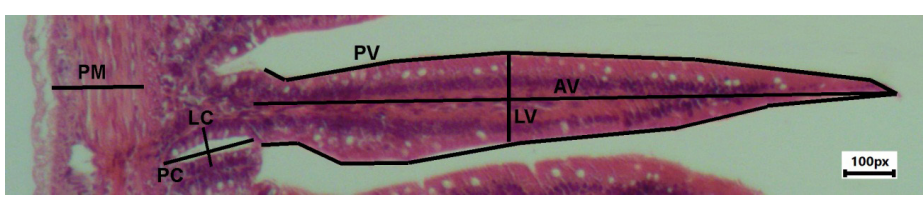

Figure 1 - Photomicrograph showing how the variables were measured, being: PM Thickness of the muscular layer of the Intestinal wall; LC - Crypt width; PC - Depth of the crypt; LV - Width of the villus; AV Height of villus; PV - Perimeter of the villus. HE coloring. $4 \mathrm{X}$ objective.

\section{Carcassyield}

Two broilers were selected according to the average weight of the experimental unit. They were then identified and maintained for 8 hours in the fasted state. Subsequently they were weighed to obtain fasting weight, slaughtered, bled, plucked and eviscerated. The feet, neck and head were removed, and then the cleaned carcass was weighed and subsequently the cuts, separately. The carcass yield was obtained by means of the relationship between the weight of the eviscerated carcass, without feet, head and neck, and live weight of broilers fasted at slaughter. The main cuts, breasts, thighs and overcoats, wings and back were weighed and their yields, calculated in relation to the weight of the eviscerated carcass.

\section{Statistic}

Data were submitted to analysis of variance by the SAS GLM procedure (Statistical Analysis System, 9.0). The Dunnett test ( $\alpha=0.05$ ) was used to verify significant differences between the positive control treatment and the yeast and enzymatic blend factorials. The yeast level estimates were established using linear and polynomial regression models and the means were compared by the SNK test with $\alpha=0.05$.

\section{RESULTS}

\section{Performance}

There was an interaction $(p<0.05)$ between the yeast levels and the enzyme supplementation for feed intake in the 22 to 33 days of age phase (Table 2).

When there was an interaction effect, or simple effect of yeast levels, a polynomial regression analysis was performed (Table 3).

There was no statistical difference between the treatments with and without the addition of the enzymatic blend in the performance variables in the phase of 22 to 33 days of age. 
Sousa RF, Dourado LRB, Lopes JB,

Fernandes ML, Kato RK,

Nascimento DCN, Sakomura NK,

Lima SBP, Ferreira GJBC
Effect of an Enzymatic Blend and Yeast on the Performance, Carcass Yield and Histomorphometry of the Small Intestine in Broilers from 21 to 42 Days of Age

Table 2 - Effect of yeast levels of sugarcane (Saccharomyces cerevisae) with or without addition of the enzymatic blend on feed intake (FI), weight gain (WG) and feed to gain ratio (f:G) on broilers in the phases of 22 to 33 and 22 to 42 days of age.

\begin{tabular}{|c|c|c|c|c|c|c|c|c|c|c|}
\hline \multirow{2}{*}{ Variable } & \multirow[b]{2}{*}{ PC } & \multirow[b]{2}{*}{ NC } & \multicolumn{3}{|c|}{ Yeast levels (\%) } & \multirow{2}{*}{ Average } & \multirow{2}{*}{$\begin{array}{l}\text { CV } \\
(\%)\end{array}$} & \multicolumn{3}{|c|}{$p>F$} \\
\hline & & & 0 & 6 & 12 & & & $E B$ & $\mathrm{YL}$ & $E B * Y L$ \\
\hline \multicolumn{11}{|c|}{22 to 33 days } \\
\hline \multirow{3}{*}{$\begin{array}{l}\text { Fl } \\
\text { (g) }\end{array}$} & \multirow{3}{*}{$1573^{*}$} & Without $^{1}$ & 1579 & $1637 *$ & 1611 & 1609 & 1.86 & 0.735 & 0.010 & 0.036 \\
\hline & & With² & 1622 & $1636^{*}$ & 1580 & 1613 & & & & \\
\hline & & Average & 1600 & 1636 & 1596 & & & & & \\
\hline \multirow{3}{*}{$\begin{array}{l}\text { WG } \\
\text { (g) }\end{array}$} & \multirow{3}{*}{$982^{*}$} & Without & 921 & 957 & $897^{\star}$ & 925 & 4.47 & 0.250 & 0.004 & 0.590 \\
\hline & & With & $882 *$ & 953 & $887^{*}$ & 907 & & & & \\
\hline & & Average & $902 B$ & $955 \mathrm{~A}$ & $892 B$ & & & & & \\
\hline \multirow{3}{*}{$\begin{array}{l}F: G \\
(g / g)\end{array}$} & \multirow{3}{*}{$1.604 *$} & Without $^{3}$ & 1.715 & 1.715 & $1.798^{*}$ & 1.743 & 3.88 & 0.135 & 0.046 & 0.050 \\
\hline & & With ${ }^{4}$ & $1.845^{\star}$ & 1.717 & $1.783^{*}$ & 1.782 & & & & \\
\hline & & Average & 1.780 & 1.716 & 1.790 & & & & & \\
\hline \multicolumn{11}{|c|}{22 to 42 days } \\
\hline \multirow{3}{*}{$\begin{array}{l}\mathrm{Fl} \\
(\mathrm{g})\end{array}$} & \multirow{3}{*}{3152} & Without & 3109 & 3167 & 3097 & 3124 & 2.51 & 0.540 & 0.061 & 0.916 \\
\hline & & With & 3078 & 3165 & 3076 & 3106 & & & & \\
\hline & & Average & 3093 & 3166 & 3087 & & & & & \\
\hline \multirow{3}{*}{$\begin{array}{l}\text { WG } \\
\text { (g) }\end{array}$} & \multirow{3}{*}{$1751 *$} & Without & 1624 & 1662 & $1602^{*}$ & 1629 & 4.91 & 0.598 & 0.155 & 0.740 \\
\hline & & With & $1576^{*}$ & 1664 & $1602^{*}$ & 1614 & & & & \\
\hline & & Average & 1600 & 1663 & 1602 & & & & & \\
\hline \multirow{3}{*}{$\begin{array}{l}F: G \\
(g / g)\end{array}$} & \multirow{3}{*}{1.800} & Without & 1.919 & 1.907 & 1.943 & 1.920 & 5.28 & 0.797 & 0.720 & 0.792 \\
\hline & & With & 1.964 & 1.903 & 1.921 & 1.930 & & & & \\
\hline & & Average & 1.942 & 1.905 & 1.927 & & & & & \\
\hline
\end{tabular}

*It differs from the average of the positive control treatment by the Dunnett test $(p<0.05)$. Averages with the same capital letter in the row do not differ statistically by the SNK test $(p<0.05) ; \mathrm{PC}=$ Positive control; NC = negative control; WITHOUT = no enzyme complex; WITH = with enzymatic complex; $\mathrm{CV}=$ coefficient of variation; $\mathrm{EB}=$ enzyme blend $6 ; \mathrm{YL}=$ yeast levels.

It is observed, quadratic $(p<0.05)$ for feed intake for the treatments without the addition of the enzymatic blend and with addition of the blend in the phase of 22 to 33 days of age, indicating a higher consumption at the inclusion levels of 7.14 and $4.21 \%$ of yeast, respectively.

The feed to gain ratio of animals that did not receive an enzymatic blend in the diet showed a linear behavior $(p<0.05)$ increasing, while those that feedintake with EB showed a quadratic effect.

There was a quadratic effect of the yeast levels under the variable weight gain in the 22 to 33 days of age phase.

When comparing the positive control (PC) treatment with the other treatments (Table 2), it is observed that feed intake was higher at the $6 \%$ level of yeast with and without enzymatic supplementation. However, these same treatments demonstrated similar feed to gain ratio and weight gain to $P C$. It was observed that the negative control diets without yeast with enzymatic blend and $12 \%$ of yeast with and without EB showed lower weight gain and higher feed to gain ratio.

In the total period (22 to 42 days) there was no interaction between yeast levels and enzymatic supplementation. The inclusion of yeast did not have significant effect on feed intake, weight gain and $F: G$ of the animals, demonstrating that in this period the inclusion of yeast with nutritional reduction did not alter the performance of the animals.

However, for the same variable, the birds that consumed the $12 \%$ yeast diet with and without enzyme were different from the positive control.

Table 3 - Regression equations for the feed intake and Feed to gain ratio and weight gain variables of broilers, submitted to sugarcane yeast inclusion levels with and without addition of enzyme complex in the diet of 22 to 33 days of age.

\begin{tabular}{lccc}
\hline Variável & EB & Equação & Valor de $p$ \\
\hline \multirow{2}{*}{ Feed intake $(\mathrm{g})$} & Without & $\mathrm{Fl}=1578.88+16.74 \mathrm{YL}-1.173 \mathrm{YL}^{2}$ & 0.048 \\
& With & $\mathrm{Fl}=1622.04+8.008 \mathrm{YL}-0.957 \mathrm{YL}^{2}$ & 0.39 \\
\hline \multirow{2}{*}{ Feed to gain ratio $(\mathrm{g} / \mathrm{g})$} & Without & $\mathrm{F}: \mathrm{G}=1.201+0.0069 \mathrm{YL}$ & 0.015 \\
\hline \multirow{2}{*}{ weight gain $(\mathrm{g}){ }^{*}$} & With & $\mathrm{F}: \mathrm{G}=1.845-0.037 \mathrm{YL}+0.0027 \mathrm{YL}^{2}$ & 0.050 \\
\hline
\end{tabular}

$\mathrm{EB}=$ enzyme blend; $\mathrm{YL}=$ yeast levels;

* Simple effect of yeast levels 
Sousa RF, Dourado LRB, Lopes JB, Fernandes ML, Kato RK, Nascimento DCN, Sakomura NK, Lima SBP, Ferreira GJBC
Effect of an Enzymatic Blend and Yeast on the Performance, Carcass Yield and Histomorphometry of the Small Intestine in Broilers from 21 to 42 Days of Age
It was observed that the performance of birds consuming positive control diets was similar to the negative control without the enzymatic blend but was different with the addition of the enzymatic blend.

\section{Carcass yield}

Regarding the carcass yield and cuts of the broilers in the 42-day phase (Table 4), no interaction was observed between yeast levels and enzyme blend supplementation for all carcass yield and cut variables, indicating that yeast can be used in up to $12 \%$ inclusion for broilers without adding enzymes, as it does not cause losses in the carcass yield and cuts (breast, thigh, overcoat and wings). Supplementation with the enzymatic blend had no significant effect on carcass yield and cuts.

There was no significant effect on carcass yield and cut of the animals with the supplementation of up to $12 \%$ yeast in the diets at the 42 day stage.

Table 4 - Relative values of carcass yield and cuts (\%) of broiler diets containing different levels of yeast with and without the addition of enzymatic complex at 42 days of age.

\begin{tabular}{|c|c|c|c|c|c|c|c|c|c|c|}
\hline \multirow{2}{*}{ Variable (\%) } & \multirow{2}{*}{$\mathrm{CP}$} & \multirow{2}{*}{ CN } & \multicolumn{3}{|c|}{ Levels of yeast (\%) } & \multirow{2}{*}{ Average } & \multirow{2}{*}{$\begin{array}{l}\text { CV } \\
(\%)\end{array}$} & \multicolumn{3}{|c|}{$p>F$} \\
\hline & & & 0 & 6 & 12 & & & EB & $L Y$ & $E B * L Y$ \\
\hline \multirow{3}{*}{ RCARC } & \multirow{3}{*}{69.71} & Without & 68.46 & 69.37 & 69.96 & 69.26 & 3.32 & 0.066 & 0.301 & 0.699 \\
\hline & & With & 67.63 & 68.73 & 67.63 & \multirow[t]{2}{*}{67.66} & & & & \\
\hline & & Average & 67.54 & 69.05 & 68.79 & & & & & \\
\hline \multirow{3}{*}{$\mathrm{RP}$} & \multirow{3}{*}{36.65} & Without & 34.92 & 37.41 & 33.66 & 35.33 & 12.95 & 0.844 & 0.943 & 0.113 \\
\hline & & With & 36.45 & 32.77 & 37.77 & \multirow[t]{2}{*}{35.66} & & & & \\
\hline & & Average & 35.68 & 35.09 & 35.72 & & & & & \\
\hline \multirow{3}{*}{$\mathrm{RCX}$} & \multirow{3}{*}{14.78} & Without & 15.20 & 15.29 & 15.29 & 15.26 & 5.49 & 0.678 & 0.482 & 0.637 \\
\hline & & With & 14.68 & 15.47 & 15.24 & \multirow[t]{2}{*}{15.13} & & & & \\
\hline & & Average & 14.94 & 15.38 & 15.27 & & & & & \\
\hline \multirow{3}{*}{ RSCX } & \multirow{3}{*}{15.71} & Without & 16.87 & 15.99 & 15.94 & 16.27 & 6.38 & 0.942 & 0.644 & 0.355 \\
\hline & & With & 16.09 & 16.53 & 16.09 & \multirow[t]{2}{*}{16.24} & & & & \\
\hline & & Average & 16.48 & 16.26 & 16.02 & & & & & \\
\hline \multirow{3}{*}{ RASA } & \multirow{3}{*}{11.08} & Without & 11.42 & 11.08 & 10.94 & 11.14 & 5.35 & 0.115 & 0.934 & 0.129 \\
\hline & & With & 11.13 & 11.13 & 11.67 & \multirow[t]{2}{*}{11.31} & & & & \\
\hline & & Average & 11.27 & 11.10 & 11.30 & & & & & \\
\hline
\end{tabular}

PC- positive control; NC- negative control; RCARC- carcass yield; RP- breast yield. RCX- tight yield; RSCX - overcoat yield; RASA- wing yield; EB- enzymatic complex; YL - yeast level; $C V$-coefficient of variation; $E B=$ enzymatic blend; $L Y=$ levels of yeast.

\section{Histomorphometry of the small intestine}

There was a significant interaction $(p<0.05)$ between the factors studied, demonstrating that the effect of yeast in the diet was dependent on the enzymatic blend for the duodenum crypt width at 42 days (Table 5 ).

In Table 4 we find the unfolding values for the interaction between yeast and enzyme over the crypt width in the duodenum at 42 days.

The use of the enzymatic blend at the $6 \%$ level of yeast provided wider crypts compared to animals receiving diets without enzymes $(p<0.05)$ as well as, compared to animals receiving 0 and $12 \%$ of yeast in the diet with enzymatic supplementation.

In Table 6, it was observed that there was interaction $(p<0.05)$ between the levels of yeast and enzymatic blend on the jejunum crypt depth at 42 days.

It is also observed deeper crypts in the diets with $12 \%$ of yeast without addition of the enzymatic blend in comparison to the crypts of birds that received positive control diets. Moreover, it was observed that the perimeter of villus reduced in the treatment with $12 \%$ of yeast and enzymatic blend when compared to the positive control treatment, which leads to a lower surface of absorption.

The unfolding of the crypt depth values (Table 6) showed that at the $12 \%$ level of yeast without the addition of the enzymatic blend the crypt depth was statistically higher than the $0 \%$ level. Still, the level of $6 \%$ of yeast was statistically similar $(p<0.05)$ at $0 \%$ and $12 \%$.

For the 42-day-old ileal morphometry data (Table 7 ), no significant interaction ( $p>0.05$ ) was observed for the variables measured. Besides, observe an expressive effect with the addition of the enzymatic blend on the structures of the ileal mucosa was not observed, as well as the levels of inclusion of the yeast. 
Sousa RF, Dourado LRB, Lopes JB,

Fernandes ML, Kato RK,

Nascimento DCN, Sakomura NK,

Lima SBP, Ferreira GJBC
Effect of an Enzymatic Blend and Yeast on the Performance, Carcass Yield and Histomorphometry of the Small Intestine in Broilers from 21 to 42 Days of Age

Table 5 - Effect of yeast levels and enzyme complex addition on the morphometric variables of the duodenum mucosa at 42 days

\begin{tabular}{|c|c|c|c|c|c|c|c|c|c|c|}
\hline \multirow{2}{*}{$\begin{array}{l}\text { Variable } \\
(\mu \mathrm{m})\end{array}$} & \multirow[b]{2}{*}{$C P$} & \multirow[b]{2}{*}{$\mathrm{CN}$} & \multicolumn{3}{|c|}{ Yeast levels(\%) } & \multirow[t]{2}{*}{ Average } & \multirow{2}{*}{$\begin{array}{l}\text { CV } \\
(\%)\end{array}$} & \multicolumn{3}{|c|}{$p>F$} \\
\hline & & & 0 & 6 & 12 & & & $\mathrm{YL}$ & $\mathrm{EB}$ & $E B * Y L$ \\
\hline & & Without & 188 & 191 & 198 & 192 & 14.02 & 0.370 & 0.382 & 0.571 \\
\hline \multirow[t]{3}{*}{$P C$} & 175 & With & 184 & 179 & 198 & 187 & & & & \\
\hline & & Average & 186 & 185 & 198 & & & & & \\
\hline & & Without & 903 & 925 & 1154 & 994 & 18.64 & 0.618 & 0.590 & 0.069 \\
\hline \multirow[t]{3}{*}{ AV } & 1164 & With & 1109 & 977 & 836 & 974 & & & & \\
\hline & & Average & 1006 & 951 & 995 & & & & & \\
\hline & & Sem & 62.34Aa & $55.31 \mathrm{Ab}$ & 60.72Aa & 59.46 & 9.95 & 0.090 & 0.029 & 0.002 \\
\hline \multirow[t]{3}{*}{ LC } & $61.67 *$ & Com & $56.77 \mathrm{Ba}$ & 78.21Aa* & $62.58 \mathrm{Ba}$ & 65.85 & & & & \\
\hline & & Without & 59.56 & 66.76 & 61.65 & & & & & \\
\hline & & With & 257 & 215 & 230 & 234 & 18.85 & 0.874 & 0.994 & 0.486 \\
\hline \multirow[t]{3}{*}{ LV } & 234 & Average & 223 & 257 & 239 & 240 & & & & \\
\hline & & Without & 240 & 236 & 234 & & & & & \\
\hline & & Without & 159 & 197 & 191 & 182 & 20.58 & 0.366 & 0.166 & 0.929 \\
\hline \multirow[t]{3}{*}{ PM } & 217 & With & 196 & 232 & 211 & 213 & & & & \\
\hline & & Average & 177 & 214 & 201 & & & & & \\
\hline & & Without & 1987 & 2162 & 2534 & 2228 & 15.19 & 0.636 & 0.330 & 0.178 \\
\hline \multirow[t]{3}{*}{ PV } & 2657.22 & With & 2173 & 2237 & 1973 & 2128 & & & & \\
\hline & & Average & 2080 & 2200 & 2253.64 & & & & & \\
\hline & & Without & 4.82 & 4.98 & 5.84 & 5.21 & 18.90 & 0.749 & 0.812 & 0.055 \\
\hline \multirow[t]{2}{*}{ AV/PC } & $6.78^{*}$ & With & 6.09 & 5.47 & $4.22 *$ & 5.26 & & & & \\
\hline & & Average & 5.46 & 5.23 & 5.03 & & & & & \\
\hline
\end{tabular}

* It differs from the average of the positive control treatment by the Dunnett test $(p<0.05)$;

A,B Different upper case letters in the same line indicate significant difference $(p<0.05)$ between averages by the SNK test; , b Different lowercase letters in the same column indicate significant difference $(p<0.05)$ between averages by the SNK test.

$P C=$ Positive control; NC = negative control; $C V=$ coefficient of variation; $E B=$ enzymatic blend; $Y L=$ yeast levels; $(P C)=D e p t h$ of crypt; $(A V)=$ height of villus; $(L C)=$ crypt width; $(\mathrm{LV})=$ villus width $(\mathrm{PM})=$ muscular wall $(\mathrm{PV})=$ villus perimeter; $(\mathrm{AV} / \mathrm{PC})=$ relationship villus crypt

\section{DISCUSSION}

\section{Performance}

Yeast is a food with high amounts of non-starch polysaccharides soluble with mannans (35-40\%) and glucans (55- 60\%) (Aquino et al. 2012). There are many reports of performance impairment caused by these compounds in broilers, but the effects of soluble NSPs are more pronounced in young animals than in older birds, presumably being associated with the maturity of the gastrointestinal tract of animals and ability to handle these compounds (Yasar \& Forbes 2000, Cowieson et al. 2006).

In addition, the use of NSPs also seems to be associated with the amount of these present in the diet, since it is observed that the animals that received the treatment with $12 \%$ of yeast resembled the negative control treatment in the phase of 22 to 33 days, with reduction in consumption and weight gain, while the treatment with $6 \%$ of yeast had the opposite behavior, denoting that large amounts of NSPs in the feed can cause performance losses.
When evaluating the use of the enzymatic blend there was no significant effect on the performance. According to Yamada et al. (2003), the resistance to cell wall degradation and, therefore, greater utilization of the yeast, is related to the origin of the same, because the Saccharomyces cerevisae from the alcohol distillery has a greater resistance to degradation compared to that coming from the brewery industry. In addition, the strain of Saccharomyces cerevisae exerts great importance on the degradation of the cell of this microorganism (Fleuri \& Sato, 2010), explained by the difference in composition and organization of the cell wall of these microorganisms.

Treatments with yeast without the enzymatic blend showed an increasing linear effect for feed to gain ratio. This event may be related to the fact that the animals in question do not have digestive enzymes capable of breaking the yeast cell wall. This effect became more evident as the level of yeast inclusion in the diet increased, and it is believed that the reduction in dietary utilization was possibly due to the increase in the viscosity of the digest and to restrict the access of the endogenous enzymes to the intestinal chyme. 
Sousa RF, Dourado LRB, Lopes JB, Fernandes ML, Kato RK, Nascimento DCN, Sakomura NK, Lima SBP, Ferreira GJBC
Effect of an Enzymatic Blend and Yeast on the Performance, Carcass Yield and Histomorphometry of the Small Intestine in Broilers from 21 to 42 Days of Age

Table 6 - Effect of yeast levels and enzymatic complex addition on morphometric variables of jejunal mucosa at 42 days.

\begin{tabular}{|c|c|c|c|c|c|c|c|c|c|c|}
\hline \multirow{2}{*}{$\begin{array}{l}\text { Variable } \\
(\mu \mathrm{m})\end{array}$} & \multirow[b]{2}{*}{$\mathrm{CP}$} & \multirow[b]{2}{*}{$\mathrm{CN}$} & \multicolumn{3}{|c|}{ Yeast levels(\%) } & \multirow[t]{2}{*}{ Average } & \multirow{2}{*}{$\begin{array}{l}\text { CV } \\
(\%)\end{array}$} & \multicolumn{3}{|c|}{$p>F$} \\
\hline & & & 0 & 6 & 12 & & & $\mathrm{YL}$ & $\mathrm{EB}$ & $E B * Y L$ \\
\hline & & Without & 139Ba & $154 \mathrm{ABa}$ & $214 A a^{*}$ & 169 & 19.96 & 0.127 & 0.215 & 0.032 \\
\hline \multirow[t]{3}{*}{ PC } & $140^{*}$ & With & $168 \mathrm{Aa}$ & $142 \mathrm{Aa}$ & $148 \mathrm{Aa}$ & 153 & & & & \\
\hline & & Average & 154 & 148 & 181 & & & & & \\
\hline & & Without & 862 & 959 & 759 & 860 & 20.27 & 0.126 & 0.874 & 0.604 \\
\hline \multirow[t]{3}{*}{ AV } & 963 & With & 973 & 866 & 742 & 861 & & & & \\
\hline & & Average & 917 & 913 & 751 & & & & & \\
\hline & & Without & 64.17 & 63.07 & 65.72 & 64.32 & 13.90 & 0.414 & 0.637 & 0.747 \\
\hline \multirow[t]{3}{*}{ LC } & 61.69 & With & 62.14 & 58.02 & 67.57 & 62.57 & & & & \\
\hline & & Average & 63.15 & 60.54 & 66.64 & & & & & \\
\hline & & Without & 180 & 242 & 294 & 239 & 28.71 & 0.423 & 0.114 & 0.072 \\
\hline \multirow[t]{3}{*}{ LV } & 184 & With & 226 & 172 & 191 & 197 & & & & \\
\hline & & Average & 203 & 207 & 243 & & & & & \\
\hline & & Without & 189 & 175 & 167 & 177 & 25.44 & 0.304 & 0.612 & 0.434 \\
\hline \multirow[t]{3}{*}{ PM } & 197 & With & 187 & 220 & 154 & 187 & & & & \\
\hline & & Average & 188 & 197 & 161 & & & & & \\
\hline & & Without & 1872 & 2101 & 1843 & 1939 & 16.19 & 0.053 & 0.781 & 0.200 \\
\hline \multirow[t]{3}{*}{ PV } & $2109.36^{*}$ & With & 2148 & 2049 & $1509 *$ & 1902 & & & & \\
\hline & & Average & 2010 & 2075 & 1676 & & & & & \\
\hline & & Without & 6.22 & 6.38 & 3.64 & 5.41 & 32.27 & 0.073 & 0.401 & 0.697 \\
\hline \multirow[t]{2}{*}{ AV/PC } & 7.03 & With & 6.04 & 6.64 & 5.15 & 5.94 & & & & \\
\hline & & Average & 6.13 & 6.51 & 4.40 & & & & & \\
\hline
\end{tabular}

* It differs from the average of the positive control treatment by the Dunnett test $(p<0.05)$; Averages with the same capital letter in the column did not differ statistically by the SNK test $(p<0.05)$;

A,BDifferent upper case letters in the same line indicate significant difference $(p<0.05)$ between averages by the SNK test;, , bDifferent lowercase letters in the same column indicate significant difference $(p<0.05)$ between averages by the SNK test.

$P C=$ Positive control; NC = negative control; $C V=$ coefficient of variation; $E B=$ enzymatic blend; $Y L=$ yeast levels; $(P C)=D e p t h$ of crypt; $(A V)=$ height of villus; $(L C)=$ crypt width; $(\mathrm{LV})=$ villus width $(\mathrm{PM})=$ muscular wall $(\mathrm{PV})=$ villus perimeter; $(\mathrm{AV} / \mathrm{PC})=$ relationship villus crypt

The behavior of the enzymatic blend may indicate that in the circumstances of this research it may have acted in function of the amount of the substrate in the diet and dosage of the enzymatic blend used. The negative control diet has a low amount of substrate for the enzymatic blend, since corn and soybean meal have low amount of non-starch polysaccharides compared to sugarcane yeast, so it is possible that the additive had an effect on the negative control treatment, increasing the endogenous losses of the animals, since it is believed that the additive acted as a function of the amount of the substrate, since according to Cowiesonet al. (2006) when there is a low amount of specific substrate in the diet there is an increase in endogenous losses and, therefore, performance losses.

High amounts of substrate also affect enzyme activity. According to Gonal et al. (2004) and Mourão \& Pinheiro (2009) in their studies they did not find significant effects on performance when using exogenous enzymes in the diets for broilers, according to the authors, this fact stems from the low dosage of the additive in the diet, according to which, the use of a higher dose of enzymes would probably lead to more evident results on performance when using foods with large amounts of NSPs. According to Henn (2002), for the exogenous enzymes to perform satisfactorily it is necessary not only the presence of the specific substrate in the feed but also the correct dosage of enzymes.

\section{Carcass yield}

The carcass and cuts yields were not influenced by the treatments used. It is already well documented that foods with high NSPs value and enzymatic blend have no effect on carcass yield (Bedford, 2000).

Further research using whole yeast for broilers also found no effect on carcass yield. [Grangeiro et al. (2001) when $7.5 \%$ of sugarcane yeast.] Silva et al. (2003) also did not observe a significant effect on the carcass yield with to $10 \%$ of whole yeast added to the experimental diets at 42 days of age.

\section{Histomorphometry of the small intestine}

The maintenance of the intestinal mucosa comes from two associated primary cytologic events: Cell synthesis (production and differentiation) that occurs in the crypt and along the villi, and the loss of cells at 
Sousa RF, Dourado LRB, Lopes JB,

Fernandes ML, Kato RK,

Nascimento DCN, Sakomura NK,

Lima SBP, Ferreira GJBC
Effect of an Enzymatic Blend and Yeast on the Performance, Carcass Yield and Histomorphometry of the Small Intestine in Broilers from 21 to 42 Days of Age

Table 7 - Average values of crypt depth (PC) height of vault (AV) crypt width (LC) width of villus. (LV) muscle wall (PM) perimeter of villus (PV) in the ileum of broilers fed diets with yeast supplemented with enzymatic blend at 42 days of age.

\begin{tabular}{|c|c|c|c|c|c|c|c|c|c|c|}
\hline \multirow{2}{*}{ Variable(um) } & \multirow[b]{2}{*}{$C P$} & \multirow[b]{2}{*}{$\mathrm{CN}$} & \multicolumn{3}{|c|}{ Levels of Yeast (\%) } & \multirow[t]{2}{*}{ Average } & \multirow{2}{*}{$\begin{array}{l}\text { CV } \\
(\%)\end{array}$} & \multicolumn{3}{|c|}{$p>F$} \\
\hline & & & 0 & 6 & 12 & & & $\mathrm{YL}$ & $E B$ & $E B * Y L$ \\
\hline \multirow{3}{*}{ PC } & \multirow{3}{*}{127} & Without & 156 & 147 & 133 & 146 & 30.48 & 0.795 & 0.254 & 0.862 \\
\hline & & With & 125 & 132 & 123 & 127 & & & & \\
\hline & & Average & 141 & 139 & 128 & & & & & \\
\hline \multirow{3}{*}{ AV } & \multirow{3}{*}{777} & Without & 854 & 675 & 824 & 784 & 30.51 & 0.590 & 0.071 & 0.596 \\
\hline & & With & 664 & 629 & 583 & 625 & & & & \\
\hline & & Average & 759 & 652 & 703 & & & & & \\
\hline \multirow{3}{*}{ LC } & \multirow{3}{*}{61.43} & Without & 55.87 & 56.59 & 62.63 & 58.36 & 14.64 & 0.341 & 0.205 & 0.830 \\
\hline & & With & 59.16 & 64.07 & 65.56 & 62.93 & & & & \\
\hline & & Average & 57.52 & 60.33 & 64.09 & & & & & \\
\hline \multirow{3}{*}{ LV } & \multirow{3}{*}{205} & Without & 181 & 229 & 218 & 209 & 24.13 & 0.237 & 0.599 & 0.978 \\
\hline & & With & 197 & 235 & 228 & 220 & & & & \\
\hline & & Average & 189 & 232 & 223 & & & & & \\
\hline \multirow{3}{*}{ PM } & \multirow{3}{*}{172} & Without & 248 & 226 & 212 & 229 & 33.78 & 0.666 & 0.694 & 0.994 \\
\hline & & With & 235 & 211 & 204 & 217 & & & & \\
\hline & & Average & 241 & 219 & 208 & & & & & \\
\hline \multirow{3}{*}{ PV } & \multirow{3}{*}{1773} & Without & 1840 & 1562 & 1866 & 1756 & 27.24 & 0.603 & 0.118 & 0.744 \\
\hline & & With & 1565 & 1436 & 1427 & 1476 & & & & \\
\hline & & Average & 1702 & 1499 & 1647 & & & & & \\
\hline \multirow{3}{*}{ AV/PC } & 6.32 & Without & 5.39 & 5.05 & 6.24 & 5.56 & 25.94 & 0.717 & 0.271 & 0.540 \\
\hline & & With & 5.10 & 4.96 & 4.81 & 4.96 & & & & \\
\hline & & Average & 5.24 & 5.01 & 5.53 & & & & & \\
\hline
\end{tabular}

$\mathrm{PC}=$ Positive control; $\mathrm{NC}=$ negative control; $\mathrm{CV}=$ coefficient of variation; $\mathrm{EB}=$ enzymatic blend; $\mathrm{YL}=$ yeast levels; $(\mathrm{PC})=\mathrm{Depth}$ of $\mathrm{crypt} ;(\mathrm{AV})=$ height of villus; $(\mathrm{LC})=\mathrm{crypt}$ width; $(\mathrm{LV})=$ villus width $(\mathrm{PM})=$ muscular wall $(\mathrm{PV})=$ villus perimeter; $(\mathrm{AV} / \mathrm{PC})=$ relationship villus crypt

the apex of the villi by desquamation, maintaining the digestive and absorption intestinal capacity (Pelicano et al. 2003). However, this balance between proliferation and desquamation can be altered by factors such as stress, pathogens, chemical substances and radiation (Artoni et al. 2014).

In the evaluation of the duodenum mucosa, it was observed that the yeast and the enzymatic blend increased the crypt width in relation to the positive control diet, as well as the villus / crypt ratio. It is assumed that there was an imbalance in the cellular production and celular extrusion of the intestinal epithelium of this region.

The increase in crypt sizes indicates a greater need for epithelial renewal (Boleli et al., 2002) to maintain the characteristics of the villi and not to affect the area of nutrient absorption, besides increasing the energy expenditure by the cells (Lopes et al., 2011).

For Nabuurs (1995), it is desirable that the villus / crypt ratio be high, ie that the villi are high and the crypts shallow, which indicates equilibrium in the proliferation and extrusion of the intestinal cells, because the higher the height of litter/depth of crypt ratio, the better the absorption of nutrients and the lower energy losses with cell renewal (Arruda et al., 2008).

The presence of diets with large amounts of nonstarch polysaccharides may exert a negative effect on the intestinal microbiota with greater microbial fermentation (Bedford, 2000, Santos Jr. \& Ferket, 2007) causing changes in the intestinal mucosa, leading to significant modifications in the structure and function of intestine (Wang et al. 2005). There are reports that when older, the animals have the ability to adapt to the antinutritional characteristics of foods, such as tannins and dietary fibers (Oliveira et al.2000), this may explain the lack of effect of diets with yeast on the ileal mucosa. The effects of dietary viscosity are more pronounced in young animals than in older birds, presumably associated with maturation of the gastrointestinal tract in older animals and the ability to cope with soluble polysaccharides (Yasar \& Forbes, 2000). It can be concluded that sugarcane yeast can be included in up to $12 \%$ in diets for broilers from 22 to 42 days without losses in performance. The use 
Sousa RF, Dourado LRB, Lopes JB,

Fernandes ML, Kato RK,

Nascimento DCN, Sakomura NK,

Lima SBP, Ferreira GJBC

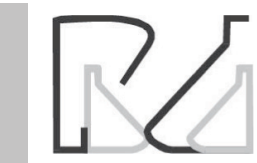

Effect of an Enzymatic Blend and Yeast on the Performance, Carcass Yield and Histomorphometry of the Small Intestine in Broilers from 21 to 42 Days of Age of yeast and enzymatic blend does not alter carcass and cuts yield at 42 days. The combined use of yeast and enzymatic blend alters the crypt dimensions of the duodenum and jejunum.

\section{REFERENCES}

Arton SMB, Nakaghi LS, Borges LL, Macari M. Sistema digestório das aves. In: Sakomura NK, Silva JHV, Costa FGP, Fernandes JBK, Hauschild L. Nutrição de não ruminantes. Jaboticabal: FUNEP; 2014. p.678.

Bedford MR. Exogenous enzymes in monogastric nutrition. Their current value and future benefits. Animal Feed Science and Technology 2000;86 (2):1-13

Behmer OA, Tolosa EMC, Neto AGF, Rodrigues CJ. Manual de técnicas para histologia normal epatológica. 2 ed. São Paulo: Editora Manole; 2003.

Boleli IC, Maiorka A, Macari M.. Estrutura fFuncional do trato digestório. In: Macari M, Furlan RL, Gonzales E. Fisiologia aviária aplicada a frangos de corte. Campinas: FACTA; 2002

Cowieson AJ, Acamovic T, Bedford MR. Using the precision-feeding bioassay to determine the efficacy of exogenous enzymes: a new perspective. Animal Feed Science Technology 2006;129(1-2):149-158.

Fleuri LF, Sato HH. Produção de protoplastos e lise da parede celular de leveduras utilizando $\beta-1,3$ glucanase. Ciência e Tecnologia de Alimentos 2010;30(2):471-476

Fleuri LF,Sato HH. $\beta$-1,3 glucanase. Biotecnica Ciência e Desenvolvimento 2007;37(1):40-43.

Franco BDGM, Langdraf M. Microbiologia dos alimentos. São Paulo: Editora Atheneu; 2008

Gona IM,Yasar S, Forbes JM. Performance and some digesta parameters of broiler chickens given low or high viscosity wheat-based diets with or without enzyme supplementation. Turkey Journal Veterinary Animal Science 2004;28(2):323-327.

Grangeiro MGA, Fuentes MFF, Freitas ER, Espíndola GB, Souza FM. Inclusão da levedura de cana- de açúcar (Saccharomyces cerevisiae) em dietas para frangos de corte. Revista Brasileira de Zootcnia 2001;30(3):766773.

Henn JD. Aditivos enzimáticos em dietas de suínos e aves [seminário]. Rio de Janeiro: UFRGS; 2002. 16 p. Available from: https://www.ufrgs.br/ lacvet/restrito/pdf/aditiv_enzimas.pdf.

Hu CH, Gu LY, Luan ZS, Song J, Zhu K. Effects of montmorillonite-zinc oxide hybrid on performance, diarrhea, intestinal permeability and morphology of weanling pigs. Animal Feed Science and Technology 2012;177(1/2):108-115.

Knudsen KEB. Fiber and nonstarch polysaccharide content and variation in common crops used in broiler diets. Poultry Science 2014;93(90):23802393
Lopes CC, Rabello CBV, Silva Júnior VA, Holanda MCR, Arruda, EMF, Silva JCR. Desempenho, digestibilidade, composição corporal e morfologia intestinal de pintos de corte recebendo dietas contendo levedura de cana-de-açúcar. Acta Scientarium Animal Science 2011;33(1):33-40.

Mourão JLTAM, Pinheiro VMC. Efeitos do centeio, do trigo e da suplementação com xilanases sobre o valor nutricional de dietas e o desempenho de frangos corte. Revista Brasileira de Zootecnia 2009;38(12):2417-2424.

Nabuurs MJA. Morphological, structural and functional changes of the small intestine of pigs at weaning. Pig News Information 16:93-97;1995

Oliveira PB, Murakami AE, Garcia ERM, Macari M, Scapinello C. Influência de fatores antinutricionais da Leucena (Leucena Leucocephala e Leucena Cunnimgan) e do feijão guandu (Cajanus Cajan) sobre o epitélio intestinal e o desempenho de frangos de corte. Revista Brasileira de Zootecnia 2000;29(2):1759-1769

Paiva JGA, Carvalho SMF, Magalhães MP, Ribeiro DG. Verniz vitral incolor 500: uma alternativa de meio de montagem economicamente viável. Acta Botanica Brasileira 2006;20(2): 257-264.

Rostagno HS, Albino LFT, Donzele JL, Gomes PC, Oliveira RF, Lopes DC, et al. Tabelas brasileiras para aves e suínos: composição de alimentos e exigências nutricionais. 3 ed. Viçosa: UFV; 2011

Pelicano ERL, Souza PA, Souza HBA, Oba A, Norkus EA, Kodawara LM, et al. Morfometria e ultra-estrutura da mucosa intestinal de frangos de corte alimentados com dietas contendo diferentes probióticos. Revista Portuguesa de CiênciasVeterinária 2003;98(547):124-134.

Sadeghi A, Toghyani M, Gheisari A. Effect of various fiber types and choice feeding of fiber on performance, gut development, humoral immunity, and fiber preference in broiler chicks. Poultry Science 2015;94(11):2734-2743.

Silva JDB, Guim A, Silva LPG. Utilização de diferentes níveis de levedura (Saccharomyces cerevisiae) em dietas e seus efeitos no desempenho, rendimento da carcaça e gordura abdominal em frangos de cortes. Acta Scietarium Animal Science 2003;25(2):285-291.

Sousa DC, Oliveira NLA, Santos ET, Guzzi A, Dourado LRB, Ferreira GJ. Caracterização morfológica do trato gastrointestinal de frangos de corte da linhagem Cobb $500^{\circledR}$. Pesquisa Veterinária Brasileira 2015;35(1):61-68.

Souza JH, Fracalossi DM, Garcia AS, Ribeiro FFT, Suzuki MY. Desempenho zootécnico e econômico de juvenis de robalo-peva alimentados com dietas contendo diferentes concentrações proteicas. Pesquisa Agropecuária Brasileira 2011;46(2):190-195.

Yamada EA, Alvim ID, Santucci MCC, Sgarbieri VC. Composição centesimal e valor protéico de levedura residual da fermentação etanólica e de seus derivados. Revista Nutrição 2003;16(4):423-432.

Yasar S, Forbe SJM. Enzyme supplementation of dry and wet wheat-based feeds for broiler chickens: performance and gut responses. British Journal Nutrition 2000;84(3):297-307 
